21. House of Commons Business, Energy and Industrial Strategy Committee. The impact of Brexit on the pharmaceutical sector: Ninth Report of Session 201719. 2018. Available at https://publications.parliament. $\mathrm{uk} / \mathrm{pa} / \mathrm{cm} 201719 / \mathrm{cmselect} / \mathrm{cmbeis} / 382 / 382 . \mathrm{pdf}$ (accessed October 2020)

22. House of Commons Exiting the EU Committee. EU Exit Analysis: Cross Whitehall Briefing. 2018. Available at https://www.parliament.uk/globalassets/ documents/commons-committees/Exiting-theEuropean-Union/17-19/Cross-Whitehall-briefing/ EU-Exit-Analysis-Cross-Whitehall-Briefing.pdf (accessed October 2020).

23. UK Government. Operation Yellowhammer. 2019. Available at https://assets.publishing.service.gov.uk/ government/uploads/system/uploads/attachment data/file/831199/20190802_Latest_Yellowhammer_ Planning_assumptions_CDL.pdf (accessed October 2020).

24. Department of Health and Social Care. How medicines, medical devices and clinical trials would be regulated if there's no Brexit deal. 2019. Available online at https://www.gov.uk/government/publications/ how-medicines-medical-devices-and-clinical-trialswould-be-regulated-if-theres-no-brexit-deal/ how-medicines-medical-devices-and-clinical-trialswould-be-regulated-if-theres-no-brexit-deal (accessed October 2020)

25. Maignen F, Berdud M, Hampson G, Lorgelly P. Public Health and Economic Implications of the United Kingdom Exiting the EU and the Single Market. 2017. Available at https://www.abpi.org.uk/media/4577/ohe-consultingpublic-health-and-economic-implications-of-the-unitedkin.pdf (accessed October 2020).

26. Kazzazi F, Pollard C, Tern P, Ayuso-Garcia A, Gillespie J, Thomsen I. Evaluating the impact of Brexit on the pharmaceutical industry. J Pharm Policy Pract 2017; DOI: 10.1186/s40545-017-0120-z.

27. European Commission. How to use the card: Employment, Social Affairs \& Inclusion. Available online at https://ec.europa.eu/social/main. isp?catld=1021\&langld=en (accessed October 2020).

28. Department of Health and Social Care, Foreign \& Commonwealth Office and Foreign, Commonwealth \& Development Office. Healthcare for UK nationals visiting the EU. 2020. Available online at https://www gov.uk/guidance/uk-residents-visiting-the-eueea-andswitzerland-healthcare (accessed October 2020).

29. Brexit Health Alliance. Briefing: Maintaining reciprocal healthcare for patients after Brexit. 2017. Available at https://www.nhsconfed.org/-/media/Confederation/ Files/Publications/Maintaining-reciprocal-healthcarefor-patients-after-Brexit.pdf (accessed October 2020).

30. Greenberg A, Jose R J. Public Health England prematurely endorses ecigarettes. BMJ 2018; DOI: 10.1136/bmj.k1262.

31. McNeill A, Brose LS, Calder R, Bauld L, Robson D. Evidence review of ecigarettes and heated tobacco products 2018: A report commissioned by Public Health England. 2018. Available at https://assets. publishing. service.gov.uk/government/uploads/system/uploads/ attachment_data/file/684963/Evidence_review_of_ecigarettes_and_heated_tobacco_products_2018.pdf (accessed October 2020).

32. House of Commons Science and Technology Committee. Ecigarettes: Seventh Report of Session 2017-19. 2018. Available at https://publications.parliament.uk/pa/ cm201719/cmselect/cmsctech/505/505.pdf (accessed October 2020).

33. European Centre for Disease Prevention and Control. ECDC's mission and main activities. 2020. Available online at https://www.ecdc.europa.eu/en/about-us/ ecdcs-mission-and-main-activities (accessed October 2020).

34. Coulthard P. Dentistry and coronavirus (COVID-19)moral decision-making. Br Dent J 2020; 228: 503-505.

35. Cancer Research UK and School of International Futures Future of clinical trials after Brexit: Final Report. 2018. Available at https://www.cancerresearchuk.org/sites/ default/files/future_of_clinical_trials_after_brexit.pdf (accessed October 2020).

36. Kings College London. Dentistry, Oral \& Craniofacial Sciences - Research Funding. 2020. Available online at https://kclpure.kcl.ac.uk/portal/en/organisations/ dental-institute(5371ed9b-7605-42a2-a51cd898c954e910)/projects.html?hesa=/dk/atira/pure/ funding/hesa/researchcouncils (accessed October 2020).

37. European Commission. Associated Countries. 2017. Available at https://ec.europa.eu/research/ participants/data/ref/h2020/grants_manual/ hi/3cpart/h2020-hi-list-ac_en.pdf (accessed October 2020).

38. Dayan M. How will our future relationship with the EU shape the NHS? 2017. Available at https://www. nuffieldtrust.org.uk/research/brexit-relationship-eushape-nhs (accessed October 2020).

39. Information Commissioner's Office. International Data Transfers. Available online at https://ico. org.uk/for-organisations/data-protection-at-theend-of-the-transition-period/data-protectionat-the-end-of-the-transition-period/the-gdpr/ international-data-transfers/ (accessed October 2020).

40. Health Education England. Advancing Dental Care: Education and Training Review - Final report. 2018. Available at https://www.hee.nhs.uk/sites/default/ files/documents/advancing_dental_care_final.pdf (accessed October 2020).

\title{
Correction to: Dental core training: the trainee perspective
}

The original article can be found online at https://doi.org/10.1038/s41415-020-1534-6

Author's correction note:

Education article Br Dent J 2020; 228: 782-790.

When initially published there were errors in the Results and Discussion section.

In the Results section, 'FigurWhile $47.6 \%$ of respondents felt that the SJT was beneficial to the application and ranking process, only $9.3 \%$ felt that it was fair, representable and realistic of real-life situations' should have read 'While $47.6 \%$ of respondents felt that the SJT was beneficial to the application and ranking process, only $10.9 \%$ felt that it was fair, representable and realistic of real-life situations.'

In the 'Situational judgement test' section of the Discussion, 'Previous stakeholder concern of the SJT have been declared, and although nearly half of all respondents (47.6\%) felt the SJT was beneficial to the process, 91.7\% felt it was not fair, realistic and representative of real-life situations, with one respondent commenting: "The SJT doesn't feel valuable to the process at all, given that a majority of the situations have never and would never arise"' should have read, 'Previous stakeholder concern of the SJT have been declared, and although nearly half of all respondents (47.6\%) felt the SJT was beneficial to the process, $78.66 \%$ felt it was not fair, realistic and representative of real-life situations, with one respondent commenting: "The SJT doesn't feel valuable to the process at all, given that a majority of the situations have never and would never arise".

The authors apologise for any inconvenience caused. 